\title{
Implementasi Model Pembelajaran Project Based Learning untuk Meningkatkan Motivasi Belajar Peserta Didik di Kelas IV SD Negeri 2 Ngadimulyo Kabupaten Temanggung
}

\author{
Tria Alfi Soraya \\ Pendidikan Profesi Guru, Pendidikan Guru Sekolah Dasar, Fakultas Ilmu Pendidikan, \\ Universitas Negeri Yogyakarta \\ Corresponding Author. Email: triaaya23@gmail.com
}

\begin{abstract}
This study aims to increase students' learning motivation using the Project based learning model in $4^{\text {th }}$ grade of SD Negeri 2 Ngadimulyo. This research is a Classroom Action Research which was carried out in two cycles. Data analysis in this study is guided by quantitative descriptive analysis. Data collection techniques were carried out by questionnaires, observations and documentation. Data analysis in this study used quantitative descriptive analysis. The results of this study indicate an increase in students' learning motivation from cycle I to cycle II. The results of the first cycle of observations reached the sufficient category, namely $68 \%$ and $69 \%$ for the results of the questionnaire which were in the sufficient category. In cycle II there was an increase in students' learning motivation with good categories, the average percentage of students' learning motivation scores from both observation sheets and questionnaires were $80 \%$ and $81 \%$.
\end{abstract}

\begin{abstract}
Abstrak: Penelitian ini bertujuan untuk meningkatkan motivasi belajar peserta didik menggunakan model pembelajaran Project based learning di kelas IV SD Negeri 2 Ngadimulyo. Penelitian ini merupakan Penelitian Tindakan Kelas yang dilaksanakan dalam dua siklus. Teknik pengumpulan data dilakukan dengan angket, observasi dan dokumentasi. Analisis data pada penelitian ini menggunakan analisis deskriptif kuantitatif. Hasil penelitian ini menunjukan adanya peningkatan motivasi belajar peserta didik dari siklus I ke siklus II. Pada hasil observasi siklus I mencapai kategori cukup yaitu 68\% dan 69\% untuk hasil angket yang berada pada kategori cukup. Pada siklus II terjadi peningkatan motivasi belajar peserta didik dengan kategori baik, perolehan persentase ratarata skor motivasi belajar peserta didik baik dari lembar observasi maupun angket yaitu $80 \%$ dan $81 \%$.
\end{abstract}

\section{Article History}

Received: 23-05-2021

Revised: $12-06-2021$

Accepted: 23-06-2021

Published: 07-07-2021

\author{
Key Words: \\ Learning \\ Motivation, Project \\ Based Learning, \\ PjBL.
}

\author{
Sejarah Artikel \\ Diterima: 23-05-2021 \\ Direvisi: 12-06-2021 \\ Disetujui: 23-06-2021 \\ Diterbitkan: 07-07-2021
}

\section{Kata Kunci:}

Motivasi Belajar, Project

Based Learning, PjBL.

How to Cite: Soraya, T. (2021). Implementasi Model Pembelajaran Project Based Learning untuk Meningkatkan Motivasi Belajar Peserta Didik di Kelas IV SD Negeri 2 Ngadimulyo Kabupaten Temanggung. Jurnal Paedagogy, 8(3), 408-413. doi:https://doi.org/10.33394/jp.v8i3.3895

\section{Pendahuluan}

Pendidikan merupakan hal yang sangat penting bagi kehidupan manusia. Pendidikan di masa pandemi Covid-19 merubah tatanan dan proses pembelajaran yang terjadi, dimana pembelajaran yang biasa dilakukan dengan tatap muka (luring) sekarang menjadi pembelajaran daring (dalam jaringan). Pembelajaran secara daring membutuhkan persiapan ekstra dan menjadi tantangan baru bagi dunia pendidikan. Sarana dan prasarana untuk pembelajaran daring harus disiapkan secara matang baik dari pihak pendidik maupun peserta didik. Pembelajaran daring akan berpengaruh pada teknologi yang dimiliki dan jaringan yang dijangkau.

Akan tetapi, tidak semua sekolah yang ada di Indonesia berhasil dengan baik melaksanakan pembelajaran secara daring, seperti yang terjadi di SD Negeri 2 Ngadimulyo. 
Berdasarkan hasil observasi yang dilakukan di kelas IV SD Negeri 2 Ngadimulyo, pembelajaran yang dilakukan di sekolah tersebut pada masa pandemi hanya meminta peserta didik untuk mengerjakan soal dan tugas saja. Instruksi tersebut diberikan melalui WhatsApp Group karena hanya melalui media tersbut peserta didik dapat mengaksesnya. Hal ini dilakukan dengan alasan minimnya fasilitas ponsel yang dimiliki peserta didik. Sebagian besar ponsel yang dimiliki digunakan orang tua peserta didik untuk bekerja, sehingga jika akan dilakukan pembelajaran daring secara penuh kurang optimal. Hal ini menimbulkan berbagai macam permasalahan seperti penguasaan materi yang kurang dikarenakan materi yang diberikan hanya melalui modul bukan penyampaian langsung oleh guru. Penguasaan materi yang kurang optimal bisa disebabkan karena kurangnya motivasi belajar. Untuk menumbuhkan motivasi belajar peserta didik guru harus mampu menciptakan suasana pembelajaran yang menarik.

Pembelajaran merupakan proses interaksi antara guru dan peserta didik sebagai komponen dalam pembelajaran. Hal ini sejalan dengan pendapat Daryanto dan Rahardjo (2012) yang menyatakan bahwa pembelajaran merupakan proses interaksi antar komponenkomponen dalam sitem pembelajaran. Guru berperan sebagai aktor utama yang akan mengatur jalannya proses pembelajaran dan peserta didik berperan sebagai subjek yang menerima materi yang diberikan oleh guru. Suatu proses pembelajaran yang komunikatif terlihat ketika terdapat komunikasi dua arah atau ada hubungan timbal balik antara guru dan peserta didik. Disamping itu, pembelajaran yang atraktif dengan dukungan media yang kreatif sangat menentukan aktivitas dan interaksi pembelajaran di kelas (Saufi \& Rizka, 2021). Dengan demikian guru juga dapat menerapkan model pembelajaran yang dapat mengaktifkan peserta didik agar tetap terjaga motivasi dalam pembelajarannya.

Mengingat luasnya permasalahan maka dalam penelitian ini akan fokus pada masalah rendahnya motivasi belajar peserta didik. Setiap guru perlu menerapkan sebuah model pembelajaran yang mengarahkan peserta didik untuk berperan secara aktif dan mencari informasi yang ada. Saat ini terdapat berbagai macam model pembelajaran yang dapat mambantu peserta didik untuk tetap interaktif. Salah satunya yaitu model pembelajaran Project Based Learning (PjBL).

Model pembelajaran Project Based Learning merupakan suatu model pembelajaran dimana peserta didik diminta untuk membentuk kelompok. Kemudian setiap kelompok membuat suatu proyek dimana proyek kelompok itu merupakan bentuk aplikasi teori yang sudah disampaikan guru. PjBL merupakan metode pembelajaran inovatif yang berpusat pada peserta didik (student centered) dan menjadikan guru sebagai fasilitator dan motivator. Project Based Learning sangat cocok diterapkan untuk meningkatkan motivasi peserta didik, dimana dalam pembelajarannya menuntun peserta didik untuk aktif dalam kerja sama mengerjakan proyek yang ditentukan. Thomas, dkk (1999) dan Handayani (2020) menyatakan bahwa pembelajaran berbasis proyek merupakan model pembelajaran yang memberikan kesempatan kepada guru untuk mengelola pembelajaran di kelas dengan melibatkan kerja proyek. Kerja proyek memuat tugas-tugas yang berdasar pada pertanyaan dan permasalahan yang menantang dan menuntut peserta didik untuk merancang, memecahkan masalah, membuat keputusan, melakukan investigasi serta memberikan kesempatan kepada peserta didik untuk bekerja dalam menuangkan ide-ide yang dimilikinya. Dengan demikian penerapan model pembelajaran Project Based Learning dapat menjadi salah satu solusi masalah dalam meningkatkan motivasi belajar peserta didik. Adapun tujuan penelitian ini adalah untuk meningkatkan motivasi belajar peserta didik menggunakan model pembelajaran Project based learning di kelas IV SD Negeri 2 Ngadimulyo. 


\section{Metode Penelitian}

Metode penelitian menggunakan penelitian tindakan kelas dengan model Kemmis \& Mc Taggart (2014) dimana setiap siklus terdiri dari empat komponen, yaitu: 1) perencanaan, 2) aksi/tindakan, 3) observasi, dan 4) refleksi. Setelah adanya refleksi lalu diikuti dengan adanya perencanaan ulang yang dilaksanakan dalam bentuk siklus tersendiri. Demikian seterusnya sampai tercapainya indikator keberhasilan yang telah ditetapkan. Model ini dapat digambarkan sebagai berikut (Arikunto dkk, 2008). Pelaksanaan penelitian dilakukan melalui 2 siklus, pelaksanaan siklus dihentikan apabila terjadi peningkatan motivasi belajar peserta didik pada pembelajaran sesuai dengan indikator keberhasilan yang telah ditentukan.Siklus I dilaksanakan dalam 2 pertemuan dan siklus 2 dilaksanakan dalam 2 pertemuan. Tujuan penggunaan desain penelitian ini yaitu apabila terdapat kekurangan atau belum terpenuhinya tujuan maka akan dilakukan perbaikan pada perencanaan dan pelaksanaan untuk bisa dilanjutkan pada siklus berikutnya sampai tujuan tercapai.

Subjek penelitian ini adalah peserta didik kelas IV SD Negeri 2 Ngadimulyo dengan jumlah peserta didik 20, yang terdiri dari 12 laki-laki dan 8 perempuan. Teknik pengumpulan data dalam penelitian ini menggunakan: 1) Observasi aitu menggunakan pedoman lembar observasi yang telah dibuat sebelumnya. 2) Angket atau kuesioner merupakan teknik pengumpulan data yang dilakukan dengan cara memberi pernyataan tertulis kepada responden untuk menjawabnya. 3) Studi dokumenter, dokumentasi yang dilakukan dalam penelitian ini yaitu pengambilan foto dan video saat proses pembelajaran berlangsung. Instumen yang digunakan dalam penelitian ini adalah 1) Lembar observasi yang digunakan dalam penelitian ini ada dua yaitu lembar observasi aktivitas guru dan peserta didik dengan model pembelajaran project based learning. 2) Angket yang akan digunakan adalah skala. Skala ini ditujukan agar dapat diketahui peningkatan motivasi belajar setelah diterapkannya model pembelajaran project based learning. Pada penelitian ini menggunakan skala Likert dengan empat alternatif pilihan jawaban yaitu selalu, sering, kadang-kadang, dan tidak pernah. Setiap jawaban pada skala akan diberi skor.

Teknik analisis data yang digunakan dalam penelitian ini menggunakan teknik analisis deskriptif kuantitatif dan kualitatif. Teknik analisis deskriptif kuantitatif digunakan untuk menganalisis persentase. Analisis dilakukan secara terus menerus atau sesudah proses pengumpulan data dilakukan dan diinterpresentasikan secara deskriptif dengan pemaknaan sesuai dengan tujuan penelitian atau kriteria keberhasilan. Data yang diperoleh dari lembar observasi dan kuesioner motivasi belajar peserta didik dihitung dan diklasifikasikan dengan teknik persentase. Formula yang digunakan untuk menghitung persentase sebagai berikut:

$$
\text { Persentase }=\frac{\text { Skoryang diperoleh }}{\text { SkorMaksimal }} \times 100 \%
$$

Hasil persentase yang telah diketahui kemudian diinterpresentasikan dalam kalimat. Berdasarkan pendapat Ngalim Purwanto (2013) maka hasil perhitungan peningkatan motivasi peserta didik dikategorikan dalam:

Tabel 1. Kategori Tingkat Motivasi Peserta Didik

\begin{tabular}{|l|l|l|}
\hline No & Persentase & Kategori Tingkat Motivasi \\
\hline 1. & $86 \%-100 \%$ & Sangat baik \\
\hline 2. & $76 \%-85 \%$ & Baik \\
\hline 3. & $60 \%-75 \%$ & Cukup \\
\hline 4. & $55 \%-59 \%$ & Kurang \\
\hline 5. & $55 \%$ & Kurang Sekali \\
\hline
\end{tabular}




\section{Hasil Penelitian dan Pembahasan}

Berdasarkan penelitian tindakan kelas yang sudah dilakukan bahwa motivasi belajar pada peserta didik kelas IV SDN 2 Ngadimulyo melalui model pembelajaran project based learning dapat meningkat. Peningkatan dapat dilihat dari hasil observasi motivasi belajar oleh observer dan angket motivasi belajar yang diberikan kepadapeserta didik. Observasi motivasi belajar peserta didik dilakukan peneliti yang dibantu oleh satu orang observer. Observasi dilakukan kepada seluruh peserta didik kelas IV SDN 2 Ngadimulyo pada saat pembelajaran berlangsung.

Pengamatan dilakukan sebanyak dua siklus. Hasil observasi pada siklus I dan siklus II menghasilkan persentase skor setiap indikator yang diamati. Kemudian persentase tersebut dihitung skor rata-ratanya. Sehingga kedua siklus dapat diamati seberapa besar persentase peningkatannya.

Tabel 2. Perbandingan Observasi Motivasi Belajar Peserta Didik

\begin{tabular}{|c|c|c|c|c|}
\hline \multirow[t]{2}{*}{ No } & \multirow[t]{2}{*}{ Indikator Motivasi Belajar } & \multicolumn{2}{|c|}{$\begin{array}{l}\text { Persentase Skor } \\
\text { Motivasi }\end{array}$} & \multirow{2}{*}{$\begin{array}{c}\text { Persentase } \\
\text { Peningkatan }\end{array}$} \\
\hline & & Siklus I & Siklus II & \\
\hline 1. & Hasrat dan keinginan berhasil & $64 \%$ & $79 \%$ & $15 \%$ \\
\hline 2. & $\begin{array}{l}\text { Dorongan dan kebutuhan dalam } \\
\text { belajar }\end{array}$ & $70 \%$ & $77 \%$ & $7 \%$ \\
\hline 3. & $\begin{array}{l}\text { Adanya harapan dan cita-cita masa } \\
\text { depan }\end{array}$ & $63 \%$ & $78 \%$ & $15 \%$ \\
\hline 4. & $\begin{array}{l}\text { Adanya penghargaan dalam } \\
\text { pembelajaran }\end{array}$ & $68 \%$ & $78 \%$ & $10 \%$ \\
\hline 5. & Kegiatan menarik & $72 \%$ & $75 \%$ & $3 \%$ \\
\hline 6. & Lingkungan belajar kondusif & $69 \%$ & $83 \%$ & $14 \%$ \\
\hline & Rata-Rata & $68 \%$ & $80 \%$ & $12 \%$ \\
\hline
\end{tabular}

Pada tabel diatas menunjukan bahwa terjadi peningkatan rata-rata skor motivasi belajar peserta didik pada siklus I dan siklus 2 berdasarkan hasil pengamatan yang dilakukan oleh observer yang mengacu pada indikator motivasi belajar peserta didik yaitu : (1) Adanya hasrat dan keinginan berhasil; (2) Adanya dorongan dan kebutuhan dalam belajar; (3) Adanya harapan dan cita-citamasa depan; (4) Adanya penghargaan dalam belajar; (5) Adanya kegiatan yang menarik dalam belajar; (6) Adanya lingkungan belajar yang kondusif. Pada pengamatan tersebut diperoleh rata-rata persentase pada siklus I sebesar $68 \%$ dan siklus II sebesar $80 \%$. Hal ini menunjukkan adanya peningkatan pada persentase motivasi belajar peserta didik pada setiap siklusnya dengan rata-rata peningkatan sebesar $12 \%$. Pada siklus II rata-rata motivasi belajar peserta didik sudah mencapai $80 \%$, sehingga dapat dikatakan sudah mencapai kategori motivasi belajar yang diharapkan.

Angket motivasi belajar dibagikan kepada peserta didik pada setiap akhir pertemuan di setiap siklusnya. Hal ini bertujuan agar motivasi peserta didik dapat dilihat dari sudut pandang peserta didik. Keberhasilan tindakan dapat dilihat dari selisih antara persentase skor angket motivasi pada siklus I dan siklus II.

Hasil angket pada siklus I, motivasi belajar peserta didik rata -rata masuk pada kategori tinggi dengan cukup 71,875\%, artinya peserta didikbelum mencapai kriteria kategori yang diharapkan. Pada siklus II, terjadi peningkatan persentase motivasi belajar pada peserta didik. Dalam kategori baik dengan persentase rata-rata 76\%. Meski demikian motivasi belajar peserta didik yang diharapkan adalah kategori sangat baik dengan kriteria $86 \%-100 \%$. 
Pada siklus 3 terjadi peningkatan yang signifikan yaitu dengan rata-rata persentase motivasi belajar peserta didik mencapai $86 \%$ dengan predikat sangat baik.

Berdasarkan uraian di atas, dapat dilihat bahwa ada peningkatan persentase motivasi belajar peserta didik dari siklus I sampai siklus II. Baik indikator yang ada pada lembar observasi maupun angket. Sebagian besar indikator yang digunakan pada keduanya sama. Data yang menunjukan peningkatan skor motivasi belajar peserta didik dari angket dapat dilihat pada tabel:

Tabel 3. Perbandingan Angket Motivasi Belajar Peserta Didik

\begin{tabular}{|c|c|c|c|c|}
\hline \multirow[t]{2}{*}{ No } & \multirow[t]{2}{*}{ Indikator Motivasi Belajar } & \multicolumn{2}{|c|}{$\begin{array}{l}\text { Persentase Skor } \\
\text { Motivasi }\end{array}$} & \multirow{2}{*}{$\begin{array}{l}\text { Persentase } \\
\text { Peningkatan }\end{array}$} \\
\hline & & Siklus I & Siklus II & \\
\hline 1. & Hasrat dan keinginan berhasil & $70 \%$ & $80 \%$ & $10 \%$ \\
\hline 2. & $\begin{array}{l}\text { Dorongan dan kebutuhan dalam } \\
\text { belajar }\end{array}$ & $71 \%$ & $79 \%$ & $8 \%$ \\
\hline 3. & $\begin{array}{l}\text { Adanya harapan dan cita-cita masa } \\
\text { depan }\end{array}$ & $69 \%$ & $80 \%$ & $9 \%$ \\
\hline 4. & $\begin{array}{l}\text { Adanya penghargaan dalam } \\
\text { pembelajaran }\end{array}$ & $66 \%$ & $79 \%$ & $13 \%$ \\
\hline 5. & Kegiatan menarik & $68 \%$ & $80 \%$ & $9 \%$ \\
\hline 6. & Lingkungan belajar kondusif & $68 \%$ & $86 \%$ & $18 \%$ \\
\hline & Rata-Rata & $69 \%$ & $81 \%$ & $12 \%$ \\
\hline
\end{tabular}

\section{Kesimpulan}

Berdasarkan hasil penelitian dan analisis data yang telah dilakukan dapat diambil kesimpulan bahwa motivasi belajar peserta didik menggunakan model pembelajaran Project based learning di kelas IV SD Negeri 2 Ngadimulyo mengalami peningkatan. Hal ini didukung oleh data-data berikut: (1) Siklus I perolehan persentase rata-rata skor motivasi belajar peserta didik baik dari lembar observasi maupun angket masing-masing yaitu $68 \%$ dan $69 \%$. (2) Siklus II mengalami peningkatan dengan perolehan persentase rata-rata skor motivasi belajar peserta didik baik dari lembar observasi maupun angket yaitu $80 \%$ dan $81 \%$.

\section{Saran}

Adapun saran yang dapat disampaikan berdasarkan hasil penelitian ini antara lain adalah; (1) Pada proses pembelajaran, guru perlu menerapkan model pembelajaran yang bervariatif aga dapat meningkatkan motivasi belajar peserta didik. (2) Sebaiknya guru senantiasa merefleksi kelebihan dan kelemahan dalam setiap pembelajaran yang dilaksanakan, agar dapat memecahkan dan mengatasi masalah yang ada.

\section{Daftar Pustaka}

Arikunto, Suharsimi dkk. (2008). Penelitian Tindakan Kelas. Jakarta: Bumi Aksara. Doyin, Mukh. (2013). Tata Tulis Karya Ilmiah. Semarang: Bandungan Institute Elisabet, Stefanus. (2019). Upaya Meningkatkan Motivasi dan Hasil Belajar IPA dengan Menggunakan Model Project Based Learning (PjBL), Vol. 3 Nomor 3 Tahun 2019 Handayani, L. (2020). Peningkatan Motivasi Belajar IPA Melalui Model Pembelajaran Project Based Learning pada Masa Pandemi Covid-19 bagi Siswa SMP Negeri 4 
Gunungsari. Jurnal Paedagogy,

$7(3)$

168-174. doi:https://doi.org/10.33394/jp.v7i3.2726

Hapsari, Dyana Indri. (2018). Penerapan Project Based Learning untuk Meningkatkan Motivasi Belajar Matematika Peserta Didik Kelas V Vol 5 No 2. Salatiga: UKSW

Hendratni, Ratna W., Budiharti. 2017. Pengembangan Media Pembelajaran Bangun Datar Berbasis Miniatur Rumah pada Mata Pelajaran Matematika SD Vol 3 No 1. Yogyakarta: UPY.

Kemmis, S., \& McTaggart, R. (2014). The Action Research Planner. Geelong: Deakin University Press.

Lubis, Fitri Agustina. (2018). Upaya Meningkatkan Kreativitas Siswa Melalui Model Project Based Learning, Vol. 1 Nomor 3 Tahun 2018 Hal 192-201.

Permendiknas. (2006). Peraturan Menteri Pendidikan Nasional Nomor 22 Tahun 2006 tentang Standar Kompetensi Lulusan.

Sari, Dewi Puspita. (2018). Meningkatkan Kreativitas Belajar Siswa Menggunakan Model Pembelajaran Project Based Learning pada Mata Pelajaran IPA di Kelas VB SD Negeri 34/I Teratai. Jambi: Universitas Jambi.

Saufi, I., \& Rizka, M. (2021). Analisis Pengaruh Media Pembelajaran Film Dokumenter Terhadap Motivasi Belajar Siswa. Jurnal Teknologi Pendidikan : Jurnal Penelitian dan Pengembangan Pembelajaran, 6(1), 55-59. doi:https://doi.org/10.33394/jtp.v6i1.3626

Setianingrum, Elisabeth. (2017). Upaya Meningkatkan Kreativitas dengan Menggunakan Pendekatan Project Based Learning pada Pokok Bahasan Klasifikasi Produk pada Siswa SMK Kelas XI Pemasaran 1 SMKN 2 Magelang. Semarang: UNNES

Sukmadinata, Nana Syaodih. (2016). Metode Penelitian Pendidikan. Bandung: PT Remaja Rosdakarya.

Sugiyono. (2016). Metode Penelitian Kuantitatif, Kualitatif, dan R\&D. Bandung: Alfabeta.

Trowbridge, L.W. (1990). Becoming a Secondary School Science Teacher. Ohio: Merrill Publishing Company. 